\title{
Innovations and Online Marketing Services Trends in Albanian Tourism Sector
}

\author{
Elton Noti, Phd \\ University "Alexander Moisiu", Durres \\ eltonoti@gmail.com \\ Brunela Trebicka, Phd \\ University "Alexander Moisiu", Durres \\ brunelat@hotmail.com
}

Abstract

\begin{abstract}
Albania is a rich country with a lot of nature and cultural tourism resources situated in the in the Balkans region where there are much opportunities for developing different types of tourism. After a long period of transition, since the fall of the communist regime in 1990, the tourism industry began to be considered as one of the economic sectors with potential for development in the future. But, tourism enterprises had to be faced with a high competition from other countries in the region and a lack of experience in the field of tourism services. This study aims to identify the attitudes of senior management of tourism enterprises (Accommodation units, Travel Agencies and Restaurants) on the adoption of new services on the Internet, the use of ICT to sell the services offered and how much they were aware of the benefits that online marketing brought using their websites etc. To realize the aim, are raised the research questions and hypotheses. The research instrument used was a questionnaire. The sample consisted of $N=208$ participants, representatives of tourism enterprises at five districts of Albania, respectively: Tirana, Durres, Shkodra, Vlore and Saranda. The results show that the entrepreneurs/managers make a very good job for the creation of new services via the Internet, also they support significantly the use of ICT-s to sell their services, they were aware of the benefits that brought a website to the marketing of tourism services and there was a great interest to learn more about the internet.
\end{abstract}

Keywords: marketing, ICT-s, innovations, tourism services, Albania

\section{Introduction}

Tourism is an industry where competition is very high and some of the competitive dimensions in this area are the innovations in the field of online marketing. Albania is a country still in transition, where after 50 years into an isolated political and economical system, the private tourism enterprises that provide tourism services have to be faced with a number of challenges related to quality and innovation in information technology and marketing .

For a short time, the online marketing became a worldwide phenomenon, by shifting the interest of new tourism developments towards it. One of the main reasons for the increased attention to marketing is that it represents the trend of the time. On the other hand, seeing the advances in technology, it's activities have supported the tourism industry too much. This is shown nowadays through the increasing level of internet use by different age groups motivated by the tourism products or services search.

The online marketing, as well as other profiles of electronic services are become a model applicable in many countries of Europe and beyond, which provide further benefits through online presence. Given the fact that there are the resources needed (do not need much capital available) and the tendency of today's tourism enterprises to online marketing and electronic services, would be necessary to be undertaken a study regarding the argumentation why it is necessary to use online marketing and what is the most appropriate profile of electronic services to be provided on a website.

The revolution in information and communication technology (ICT ) has changed not only lives, but also the way people do business. Tourism is characterized by the need to ensure quick and accurate information for the consumer. The first step to achieve this objective, a so-called "one -stop" is through the Global Distribution Systems (GDS), a form of the InterOrganizational Systems (IOS). GDS-s have evolved from computerized systems reservation (CRS) and have facilitated the collection of information from airlines, which enables travel agents (as a mediator of information) as well as tourists to make reservations and other services in a single market $(\mathrm{Jo0}, 2002)$. 
Regarding the internet access in Albania according to AKEP (2015), the number of subscribers with broadband access from fixed networks by the end of 2014 was about 207,000, compared to 183,000 in 2013, representing an annual increase of $13.3 \%$. All the main operators of fixed internet in Albanian market have increased the number of subscribers for the year 2014. The number of mobile subscribers who have broadband access by using wireless networks (3G USB cards/modems and handsets) in 2014 was 1.4 million or $16 \%$ more than in 2013. The use of $3 \mathrm{G}$ broadband access networks has been increased with $59 \%$ for the access via USB/modem, and $12 \%$ through via mobile devices. The rate of penetration (number of subscribers per 100 inhabitants) of fixed network broadband access by the end of 2014 was $31.7 \%$ compared with 6.40 $\%$ in 2013.

\subsection{The aim and research questions}

This study aims to identify the attitudes of senior management of tourism enterprises (Accommodation units, Travel Agencies and Restaurants) on the adoption of new services on the Internet, the use of ICT to sell the services offered and how much they were aware of the benefits that online marketing brought using their websites

1- Are managers aware of the benefits of a website in the marketing of tourism services?

2- Are managers / entrepreneurs likely to introduce innovative online services?

3- Is there interest in learning more about online services?

\section{Literature review}

The tourism industry consists of many business activities such as: the accommodation sector, travel agencies, restaurants, bars, various activities related with transportation services, product manufacturing activities, crafts, cultural activities, sports, different parks (archaeological, natural, national, etc.), museums etc.

But this study is focused on the accommodation sector, travel agencies and restaurants as main sectors in Albania, which use extensively the information and communication technologies for business purposes.

The use with creativity of corporate websites and their connection with the search engines and other appropriate sites are considered an important part of achieving customer awareness and motivation. The influence of advertising, has reached to penetrate visibly to customers, who are looking for services/products that are advertised, after their demands match exactly with that product/service and the provider who trades them and not with others who can be offered.

The trade developments through Internet during recent years, have used the network as an excellent instrument with relatively low cost for creating customer awareness, using multimedia methods, which can be supported as well through the provision of printed information to potential buyers who have shown interest in advance. At the same time, they can at least partially replace expensive brochures, having the same information or other online resources such as the website's options "download".

Improvements in reservation systems that have occurred during last year's, have made it easier for the sector to develop and combine tourist itineraries, in a very simple and fast manner to customers.

Likewise, sophisticated postal databases systems, based on computers have become facilitator instruments, contributing to realize marketing processes more easily and accurately.

Developments in the field of communication technology and entertainment, are forcing businesses, which provide services to business travelers, to modify their products and services including :

- Mobile phones on aircraft seats, computer games and even to the mini - casino

- Equipment with special effects at conference rooms

- Access to the Internet and mini - offices in hotel rooms ( Swarbrooke and Horner , 2001).

New forms of using online applications and their application in tourism industry. 
Currently, Web 2.0 and "user-generated information " are the biggest online developments, which are reshaping the traditional marketing methods in tourism businesses (Reactive , 2007). Traditional marketing methods like the"word of mouth " is changing significantly. Introduction of web 2.0 technology played a major role in how consumers of a service or product evaluate that experience. Within the context of the tourism industry, this can be achieved by exchanging pictures, travel blogs, video sharing, etc . Before entering the Web 2.0 customers were only able to be engaged in research information and in some cases even be included in any purchase. Now, consumers are able to identify, edit, comment and buy products/ services. Web 2.0 has put tourists between functionality and product distribution.

There are many blogs in the tourism industry such as: tripadvisor.com, hotelchatter.com, booking.com etc. Every person can create a blog in web using the free applications, such as google search engine, which can be used to publish links of other blogs, texts, images, video and audio etc. (Sigal, 2007).

The online services trends mentioned above have a something in common that are focused on the customer. Social media and "user-generated information" are technologies dictated by the costumer. One implication of these trends online, means that customers now have more control over the decision to travel, thus making tourism. But often, traders have less control in the fact that the message was perceived as relevant to the audience they are addressing. But this loss of control does not mean necessarily to have negative effects as web-sites generated by users can create a kind of loyalty and can establish a close link between the customer and the service provider (Cox et al., 2007) .

The tourism industry in general, is widely influenced by the technological revolution . Either tourist destination, or tourist enterprises, need to adopt innovative methods and boost their competitiveness in this business. For his part, the new customer is full of knowledge and seeking more and more information becomes more and more familiar with innovation, demanding flexible services, specialized, accessible, interactive and communications products with main entrepreneurs. Therefore, day by day are launched the best practices regarding new management tactics, taking advantage of the technological revolution and new processes in business operations and dynamics of the industry.

According to Buhalis (1998), can be pursued two strategic directions: tourism enterprises or may provide value differentiated from competitors by developing programs of high quality and personalized, for which consumers will be willing to pay a price high, or they can provide cost value, offering less expensive products than those of competitors, through standardization and consolidation and quantity. He also suggests a strategic framework, demonstrating how ICT-s can contribute to the development of the strategy of tourism business, and all possible interactions between tourism enterprises and their clients, but must be updated to technological progress, the adapt to new services that may be offered .

\section{Methodology}

In this paper is used the quantitative method approach through the use of surveys to collect data.

Research Context. The study was conducted in five areas of Albania, known as main tourism destinations from north to south such as: Tirana, Vlora, Durres, Shkodra and Saranda. Sampling is based on a list of registered tourism enterprises in Albanian Tourism Association (ATA) and is referred to three types of tourism services: accommodation units, travel agencies and restaurants. Once the respective districts have been selected, then, it is taken a percentage from each district.

Sampling. In this study, was included one of the most common models of non probability sampling called quota sampling. Data analysis was realized through the statistical software SPSS 16.

Inclusion criteria. To participate in the study, participants must be over the age of 18 and had the primary responsibility to manage a tourism enterprise. They could be self owners, key managers or when they were not found, could be old employees. In other cases, have participated ICT specialists employed in the relevant enterprises. Research tool. In order to realize the study as a research tool was used a questionnaire.

Procedures of gathering data. The method of data collection for this study was that of a face -to-face interview. 


\section{Results}

The three types of activities that have participated in this study, according to predetermined criteria, were: accommodation units at a rate of $56.2 \%$, travel agencies at $22.1 \%$ and restaurants at $21.6 \%$. In the field of tourism usually these are the types of activities that are studied. As regards the period of starting the business, the enterprises had an average of 10 years that they were operating in the market.

In the table 1 is introduced the level of know - how and innovations offered by the Internet within the company. According to the table, the enterprises which participated in this study agree with the statement that they do a lot for creating new services via the Internet $(78.9 \%)$, the entrepreneurs or managers have supported the use of ICT-s for selling the services offered (82.2 \%) they had invested in the development of ICT and website - it ( $85.1 \%$ ) and were aware of the benefits that a website has in the marketing of tourism services ( $85.1 \%)$. Also, they claimed that there is a great interest in learning about the internet and new information technology in the field of tourism $(91.8 \%$ )

Table 1. The level of knowledge ( know - how ) and innovations offered through the Internet within the company

\begin{tabular}{|c|c|c|c|c|c|}
\hline & $\begin{array}{l}\text { Strongly } \\
\text { disagree } \\
\end{array}$ & Disagree & $\frac{\text { Neutr }}{\text { al }}$ & Agree & $\begin{array}{l}\text { Strongly } \\
\text { agree } \\
\end{array}$ \\
\hline $\begin{array}{l}\text { We do a very good job for the creation of new services via } \\
\text { the Internet }\end{array}$ & $1.4 \%$ & $4.8 \%$ & $14.9 \%$ & $51.0 \%$ & $27.9 \%$ \\
\hline $\begin{array}{l}\text { Entrepreneurs or managers significantly supports the use of } \\
\text { information technology and the Internet to sell the services }\end{array}$ & $1.9 \%$ & $3.4 \%$ & $12.5 \%$ & $51.0 \%$ & $31.2 \%$ \\
\hline $\begin{array}{l}\text { Entrepreneur / manager has invested enough in developing } \\
\text { information technology and website - it }\end{array}$ & $1.0 \%$ & $10.6 \%$ & $19.2 \%$ & $43.3 \%$ & $26.0 \%$ \\
\hline $\begin{array}{l}\text { Senior management is aware of the benefits of a website in } \\
\text { the marketing of tourist services }\end{array}$ & $1.0 \%$ & $4.3 \%$ & $9.6 \%$ & $49.0 \%$ & $36.1 \%$ \\
\hline $\begin{array}{l}\text { Generally, there is a great interest in learning about the } \\
\text { internet and new information technology in the field of }\end{array}$ & $.5 \%$ & $1.4 \%$ & $6.2 \%$ & $27.9 \%$ & $63.9 \%$ \\
\hline
\end{tabular}

\section{The relation between know - how and skills to use the website}

The level to which the enterprise recognizes and invests in ICT is very important for the future of it in relation with ICT. The employees themselves may be more adaptive or not to ICT-s. In this study the correlation between the know - how of entrepreneurship and complex skills or not to use the website, is moderately positive $\left(r_{s}=.386, p<.001\right)$, (Table 2$)$.

Table 2. The relation between know - how and skills to use the website

Know - how Skills

Spearman's rho Know - how Correlation

Coefficient

${ }^{* *}$. The correlation is statistically significant at the level 0.01 (2-tailed). 


\section{Conclusions}

The enterprises in this study reported the highest levels of information technology use in their daily work. This indicator is positive and also related to their positions, which were as well positive about information technology. ICT is often used as a marketing tool, aiming at a wider market. In this study, the entrepreneurs expressed positively to it's use as a marketing tool, however the levels are not too high.

According to responses, the online marketing through a website is extensively widespread in Albania and enterprises themselves have monitored what other companies do in terms of website use and designs. A large part of them are active participants in social networks like facebook, twitter etc. Also, a relatively large part was listed in external web portals, which make possible online bookings and service sales and argued that promotional activities via the Internet are very effective way to reach new market segments.

\section{Recommendations}

- Quality improvement of websites, especially in the sector of accommodation units.

- Participation of staff in professional trainings on innovation in the field of ICT-s in tourism.

- Recruitment of staff specialized in designing and updating information on online services

- Raising awareness of entrepreneurs on further investment in innovation related to online services.

- Inclusion of the possibility of e- commerce through the websites for the three types of tourism enterprises.

\section{References}

AKEP.(2015). Raporti Vjetor i Veprimtarisë për Vitin 2014 [eng. Annual report of Activities 2014], Autoriteti i Komunikimeve Elektronike dhe Postare [eng. Authority of Electronic and Postal Communications], pp 38 - 40, Tirana

Buhalis, D. (1998). Strategic use of information technologies in the tourism industry. Tourism Management 19(5):409-421

Cox, C., Burgess, S., Sellitto, C. dhe Buultjens, J. (2007). Consumer-generated web-based tourism marketing. CRC for Sustainable Tourism. Australia

Joo, J. (2002). A business model and its development strategies for electronic tourism markets', Information Systems Management, (19), 3, pp. 58-69

Reactive (2007), Web 2.0 for the Tourism \& Travel Industry, Reactive, Australia

Sigala, M. (2007) WEB 2.0 in the tourism industry: A new tourism generation and new e-businessmodels, TDN International Edition, [http://www.traveldailynews.com/pages/show_page/20554 as accessed on 12 Secember 2013]

Swarbrooke, J. and Horner, S. (2001). Businnes Travel and Tourism, pp 265 